\title{
Periphyton communities in carp culture ponds treated with cow manure and biogas slurry
}

\author{
Madhumita Das*, Pralaya Ranjan Behera and Biswajit Dash \\ Visakhapatnam Regional Centre, Central Marine Fisheries Research Institute, Visakhapatnam, Andhra Pradesh, India
}

Received 11 October 2016 / Accepted 22 June 2017

Handling Editor: Véronique Martin-Jezequel

\begin{abstract}
The mean periphyton counts in the surface and subsurface waters of the fish ponds with applications of cow manure at $10 \mathrm{t} / \mathrm{ha} / \mathrm{yr}$; urea at $100 \mathrm{~kg} \mathrm{~N} / \mathrm{ha} / \mathrm{yr}$ and single super phosphate at $50 \mathrm{~kg} \mathrm{P} / \mathrm{ha} / \mathrm{yr}$ in the first treatment; biogas slurry at $15 \mathrm{t} / \mathrm{ha} / \mathrm{yr}$ and inorganic fertilizers as in the previous treatment in the second treatment; biogas slurry at $30 \mathrm{t} / \mathrm{ha} / \mathrm{yr}$ in the third and biogas slurry at $30 \mathrm{t} / \mathrm{ha} / \mathrm{yr}$ with supplementary feed were $333,365,407,433 / \mathrm{cm}^{2} /$ day and $230,284,348,377 / \mathrm{cm}^{2} /$ day, respectively. Higher counts were observed in treatment 4 , followed by treatments 3,2 and 1 showing significant differences with higher counts in the surface waters. The species diversity indices were more in the third and fourth treatments with higher diversity at the surface levels. The dominance of Bacillariophyceae in the surface waters was distinct (45.9-60.6\%) attributing to the higher nutrient availability on mineralization of the easily decomposable substrate. Water quality parameters in all the four treatments were in the normal ranges. The representations of both Bacillariophyceae and Chlorophyceae were similar in the subsurface waters $(36.6-50.8 \%$ and $28.2-$ $36.4 \%$ ). There was increase in the percentage composition of protozoans in the surface waters in the slurryapplied ponds $(0.6-3.3 \%)$. Variations in rotifers were moderate, the respective representation ranges being $0.9-3.4 \%, 2.2-5.3 \%$ in the two levels and cladocerans in subsurface waters were higher with means of 10.7 , 4.3, 4.9 and 4.7. Copepods were the dominant group in the animal assemblages at the surface level with the means of $3.0 \%, 2.3 \%, 4.0 \%$ and $5.0 \%$. The variations in the different groups presented a vertical distribution pattern in the colonization of the periphytic communities.
\end{abstract}

Keywords: Periphytic community / Surface and subsurface layers / Carp culture ponds

\section{Introduction}

Periphytic communities, the fundamental components in pond ecosystem, are assemblage of minute plants and animals on the surfaces of submerged aquatic objects and are usually found in lower biomass is low as compared to the submerged biomass present. They perform a boundary activity connecting the substratum and the surrounding waters and furthermore are the main suppliers to the energy and biomass contained at higher trophic levels. To minimize the input cost in pond production system research works in south Asian countries have been concentrated on enhancing the plankton based food web to increase nutrient efficiencies without giving importance to substrate based food web (Maiti et al., 2014; Saha et al., 2016). In different aquatic ecosystems, periphytic organisms exhibit varied dynamics and also change with experimental manipulations. Most freshwater fishes are better adapted to grazing on substrate than to filter feeding. Alluring techniques

\footnotetext{
${ }^{*}$ Corresponding author: dasmadhumita999@rediffmail.com
}

like natural substrates or artificial substrates could be provided in the submerged surfaces of freshwater ecosystems for better water quality with efficient harvest of larger food sources and encouraging impacts on production. Information on periphyton production in relation to diverse substrate use and management practices is inadequate except for some studies in rivers, lagoons, brackish water environments and fish ponds (Barbiero, 2000; Kaggwa et al., 2006; Rusanov and Khromov, 2016). In a study in a Danubian floodplain lake with the provision of glass slides as substrate, when disturbance is created showed changes in periphytic algal communities. In the beginning, diatom community dominated during spring but showed a quick change with the development of community of filamentous and stalk-forming chlorophytes during summer (Pfeiffer et al., 2015). This has been understood that several environmental factors such as changes in temperature and light intensity affect periphytic growth rates (El-Sabaawi and Harrison, 2006). Dempster et al. (1993) and van Dam et al. (2002) have analyzed the interactions between periphyton and other biotic communities. Debenest et al. (2009) have reported that periphytic diatoms are sensitive to organochlorines. 


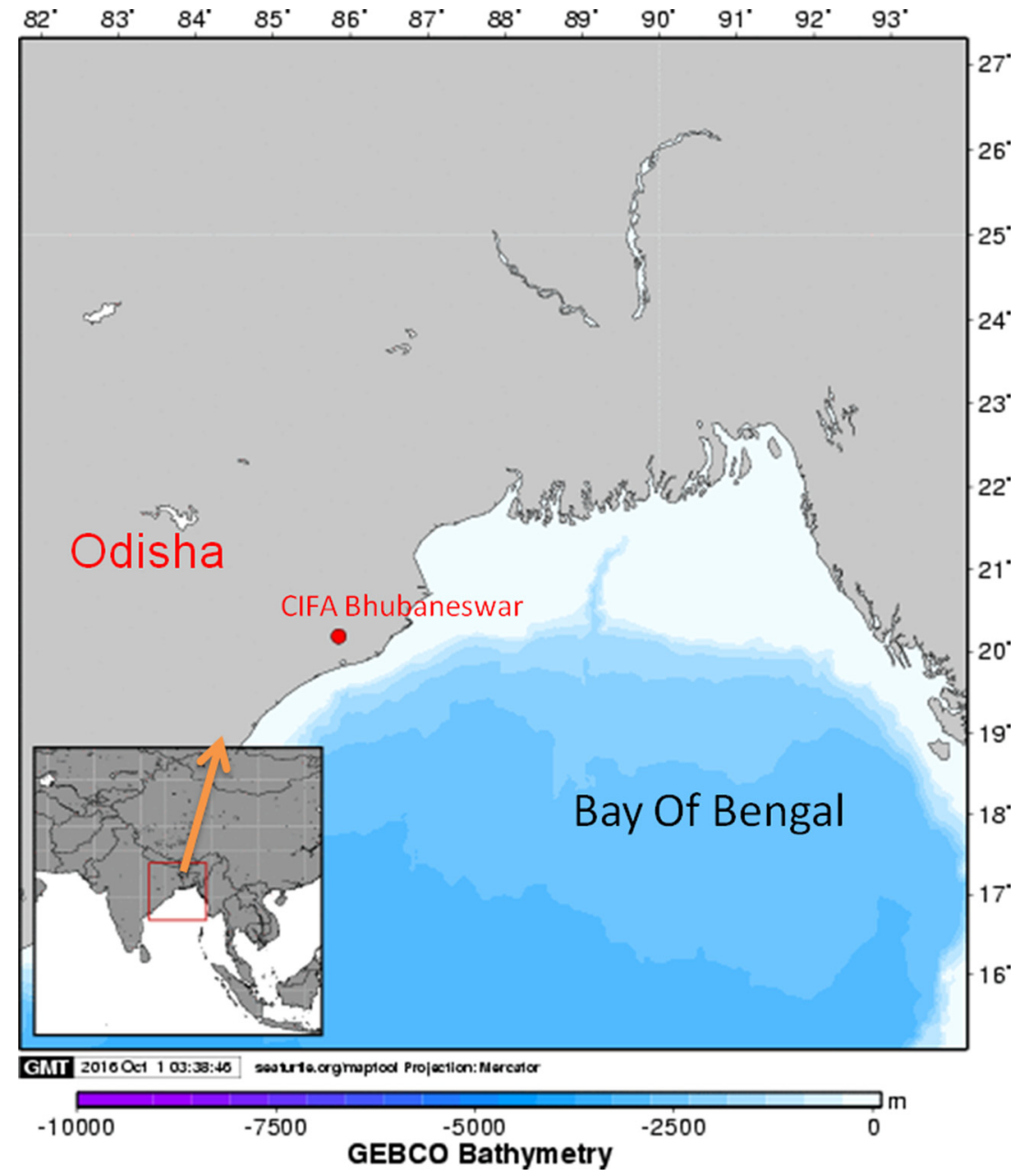

Fig. 1. Experimental pond location at Central Institute of Freshwater Aquaculture, Kausalyaganga, Bhubaneswar, Odisha, India.

Nasser and Sureshkumar (2014) have analyzed the pattern of variation in five different types of habitats and observed maximum microalgal diversity in reservoir habitat and minimum in modified habitat. Stimulating periphyton based food web is a better option than stimulating phytoplankton based food web but adding periphyton development to an aquatic system along with the already existing phytoplankton based and detritus based food webs will enhance the fish pond productivity (Milstein et al., 2009; Wang et al., 2011). Asaduzzaman et al. (2008) have described that substrate addition for periphyton development controls carbon/nitrogen ratio and development of periphyton which equally enhance freshwater prawn production in ponds.

The periphytic community, though is an integrated part of the whole system productivity and food web interactions among hydrological, climatic and nutrient factors (Dharmaraj et al., 2002; Huchette and Beveridge, 2008), it has not been given focused attention in many Indian hydrobiological investigations (Shankar et al., 1998; Keshavanath et al., 2001). Virtual status of periphytic community structure in pond ecosystems gives an indication of the nutrient status of a culture system and by the addition of both fertilizer and manure it becomes easier to manipulate the water quality for colonization and abundance of the attached algal communities for achieving better production levels. Detail studies on these aquatic biota in freshwater systems has been made by Ayyappan (1987), Azim et al. (2001), Wetzel (2001), Keshavanath et al. (2002) and Jobgen et al. (2004). In the present study an attempt has been made to understand the periphytic counts, production pattern and species diversity in the surface and subsurface waters of ponds treated with cow manure and biogas slurry at the farm of Central Institute of Freshwater Aquaculture, Kausalyaganga, Bhubaneswar, Odisha, India.

\section{Material and methods}

\subsection{Experimental design and manurial applications}

For the study, twelve ponds ( 0.04 ha each) were used at the farm of Central Institute of Freshwater Aquaculture, Kausalyaganga, Bhubaneswar, Orissa, India (Lat. 20 $11^{\prime} 06^{\prime \prime}$ $20^{\circ} 11^{\prime} 45^{\prime \prime} \mathrm{N}$; Long. $85^{\circ} 50^{\prime} 52^{\prime \prime}-85^{\circ} 51^{\prime} 35^{\prime \prime} \mathrm{E}$ ) (Fig. 1). There were four manurial treatments in triplicates, with applications of cow manure at $10 \mathrm{t} / \mathrm{ha} / \mathrm{yr}$, urea at $100 \mathrm{~kg} \mathrm{~N} / \mathrm{ha} / \mathrm{yr}$ and single super phosphate at $50 \mathrm{kgP} / \mathrm{ha} / \mathrm{yr}$ in the first treatment (1), biogas slurry at $15 \mathrm{t} / \mathrm{ha} / \mathrm{yr}$ and inorganic fertilizers as in the previous treatment in the second treatment (2), biogas slurry at $30 \mathrm{t} / \mathrm{ha} / \mathrm{yr}$ in the third (3) and biogas slurry at $30 \mathrm{t} / \mathrm{ha} / \mathrm{yr}$ with supplementary feed (4) (rice bran and groundnut oil cake of 
Table 1. Mean counts and abundance of periphyton (no. $/ \mathrm{cm}^{2} /$ day) in surface and subsurface waters of ponds under different treatments.

\begin{tabular}{llllllll}
\hline Treatments & Mean (surface) & SE & Confidence interval (95\%) & Mean (sub surface) & SE & Confidence interval (95\%) & $p$ Value \\
\hline Treatment 1 & 332.5 & 6.61 & 14.27 & 229.85 & 7.22 & 15.59 & $8.062 \mathrm{e}-07$ \\
Treatment 2 & 365.28 & 3.87 & 8.36 & 284.21 & 5.54 & 11.96 \\
Treatment 3 & 407.28 & 6.88 & 14.86 & 348.35 & 8.03 & 17.34 & $1.192 \mathrm{e}-08$ \\
Treatment 4 & 453.35 & 3.79 & 8.18 & 377.00 & 6.67 & 14.40 & $7.514 \mathrm{e}-07$ \\
\hline
\end{tabular}

groundnut in equal proportions at $1 \%$ of fish biomass) provided daily in ponds. The ponds were stocked with carp fingerlings at a density of $5000 /$ ha in proportions of catla $15 \%$, rohu $25 \%$, mrigal $25 \%$, silver carp $30 \%$ and grass carp $5 \%$.

\subsection{Sampling and analysis}

Samples of pond waters were collected in clean polyethylene bottles from the pond surface waters and analyses for different parameters were conducted at monthly intervals through the period of study. Temperature and $\mathrm{pH}$ of pond waters were measured by mercury thermometer and $\mathrm{pH}$ meter of water analysis kit (Century, CK-710). Dissolved oxygen content of water was measured with an Oxi-meter, OXI-191 (Chemito, India). Following colorimetric methods the water quality parameters such as, $\mathrm{NH}_{4}-\mathrm{N}, \mathrm{NO}_{2}-\mathrm{N}, \mathrm{NO}_{3}-\mathrm{N}$ and $\mathrm{PO}_{4}-\mathrm{P}$ were quantified using double beam UV-Vis spectrophotometer (APHA, AWWA, WPCF, 2012).

Glass slide method was used for the study and collection of periphyton settlements at two levels from the pond waters (Sladecek and Sladeckova, 1964; APHA, AWWA, WPCF, 2012). Water level in each pond was maintained at $2 \mathrm{~m}$ and replicate glass slides (two glass slides at each level) fastened to bamboo sticks fixed to a bamboo pole at two levels, viz., surface $(0.5 \mathrm{~m}$ downwards from surface $)$ and subsurface $(1.0 \mathrm{~m}$ downwards from surface), were provided as substrates for periphytic settlement within exposure period of 4 weeks after which the same process was repeated with new slides fastened and exposed for next month. The periphytic assemblages of both the slides at each level tied at both sides of the bamboo pole were scraped on to a petridish, mixed evenly and made to a volume of $20 \mathrm{ml}$ with filtered water and preserved with $5 \%$ formaldehyde solution. The size of each slide was $7.6 \mathrm{~cm}$ $\times 2.6 \mathrm{~cm}=197.6 \mathrm{~cm}^{2}$. The periphytic assemblages of both the surfaces of the glass slides at each levels were scraped on to a petridish, mixed evenly and made to a volume of $20 \mathrm{ml}$ with sterile water and preserved with $5 \%$ formaldehyde solution. One milliliter of each sample was placed in Sedgewick Rafter plankton-counting cell and the periphytic forms were identified up to generic level qualitatively and quantitatively it was expressed as number $/ \mathrm{cm}^{2}$. Considering both sides of the slide the dilution factor was total number $/ 395=$ no. $/ \mathrm{cm}^{2}$ (Edmondson, 1959; Sladecek and Sladeckova, 1964). The populations counted in each treatment were expressed as no./ $\mathrm{cm}^{2} /$ day and the percentage compositions of algal forms and animal assemblages as well as the compositions of major groups were calculated. Diversity indices were estimated in order to compare the abundance of periphyton among different treatments at both the levels of pond ecosystems by using
PRIMER v.6 data analysis software (Clarke and Gorley, 2006). Two way ANOVA was conducted to analyze the significant difference between the periphyton assemblage between surface and subsurface water under different treatment levels. The significance difference between the means of the treatments were assessed using Tukeys honest significant difference (HSD) test using $p \leq 0.05$ as the level of significance.

\section{Results}

\subsection{Total counts}

The variations in periphyton counts in the surface and subsurface levels of ponds under different treatments for a period of 14 months in the surface and at subsurface level is given in Table 1 . Treatment 4 showed significantly higher $(p<0.05)$ periphyton counts followed by treatments 3,2 and 1 both in surface and subsurface levels (Fig. 2). The periphyton counts in all the treatments showed significant differences between surface and subsurface levels at $95 \%$ confidence interval.

\subsection{Percentage composition}

The percentage compositions of algal forms and animal assemblages at the surface and subsurface levels are presented in Figures 3 and 4. The algal fractions were higher in the total periphyton counts at both the levels. Periphyton comprised thirty five genera of algal forms represented by five genera belonging to the family Myxophyceae, eighteen genera belonging to the family Chlorophyceae, ten genera belonging to the family Bacillariophyceae, one genera belonging to the family Chrysophyceae, and one genera belonging to the family Dinophyceae.

The mean percentage compositions of animal assemblages at both the levels indicate a gradual increase in the composition of animal assemblages in the periphyton on subsurface levels, though algal dominance persisted at both the surface and subsurface levels. The genera of animal assemblages were represented by two genera of Protozoa, five genera of Rotifera, three genera of Cladocera and three genera of Copepoda.

\subsection{Generic composition}

The generic representations in the periphyton were Oscillatoria, Anabaena, Rivularia, Gloeothece, Spirulina (Myxophyceae); Pediastrum, Bulbochaete, Selenastrum, Botryococcus, Ankistrodesmus, Scenedesmus, Spirogyra, 


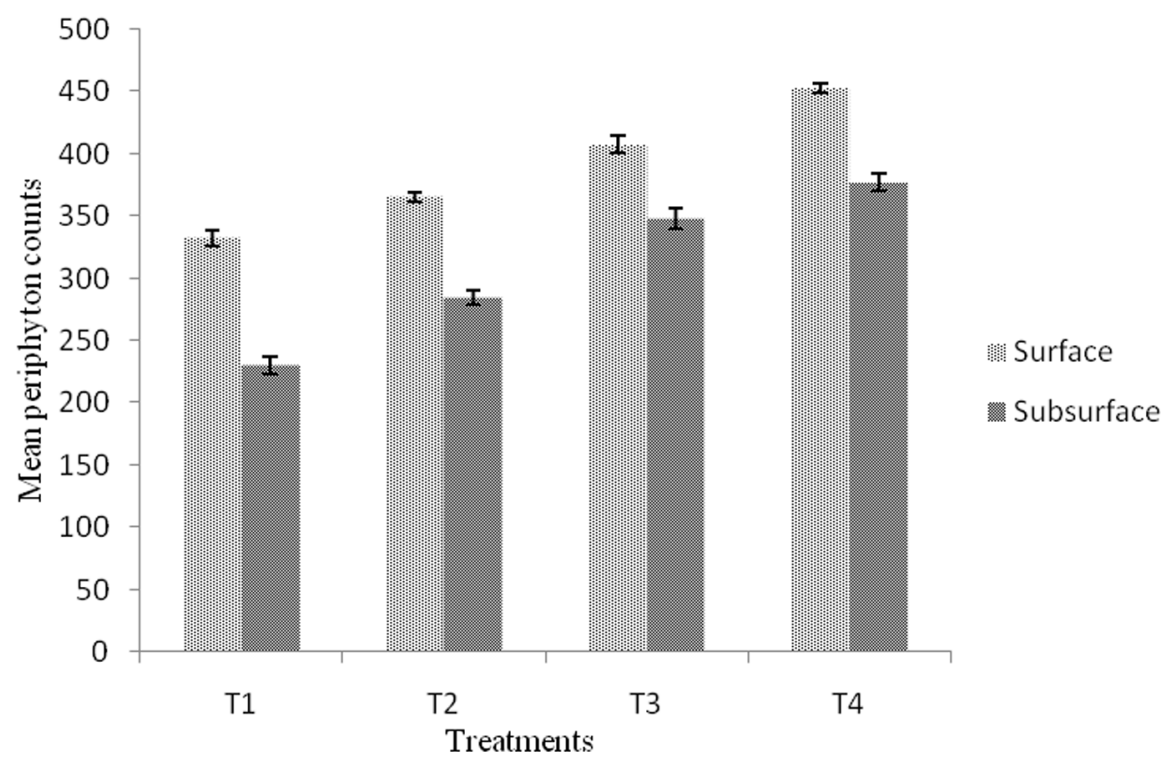

Fig. 2. Mean periphyton counts (no. $/ \mathrm{cm}^{2} /$ day) at surface and subsurface levels of ponds under four different treatments during the study period.

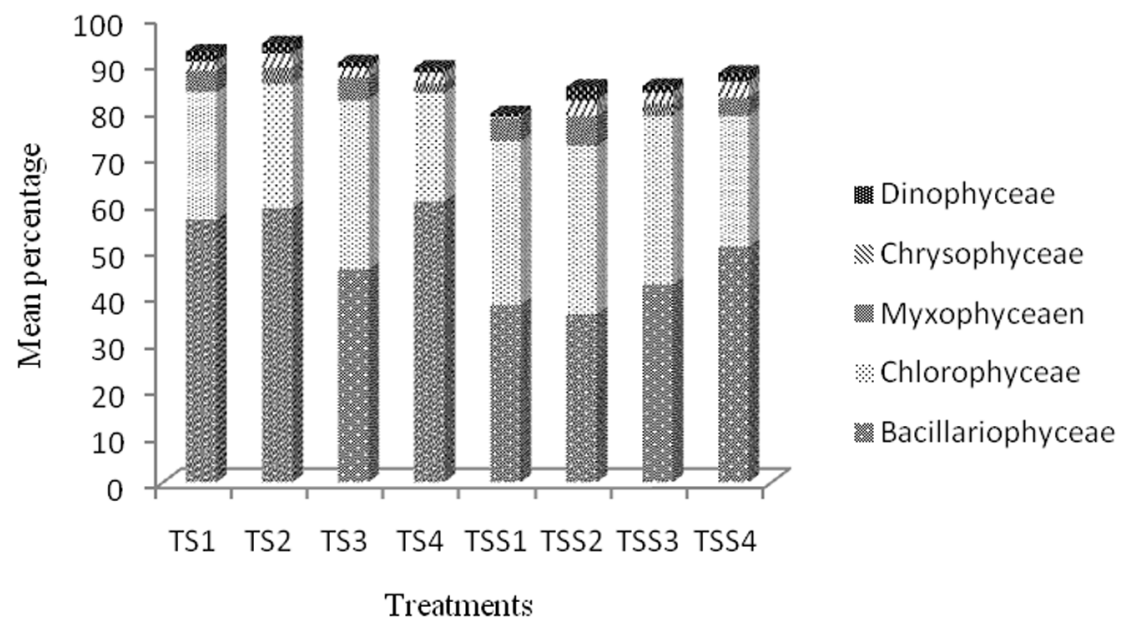

Fig. 3. Percentage compositions of algal forms at surface (TS1-TS4) and subsurface (TSS1-TSS4) levels of ponds among four different treatments during the study period.

Zygnema, Dispora, Closterium, Tetraspora, Hydrodictyon, Ulothrix, Oedogonium, Schizogonium, Actinastrum, Gongosira, Draparnaldiopsis (Chlorophyceae); Dinobryon (Chrysophyceae); Cyclotella, Nitzschia, Synedra, Navicula, Amphora, Gomphonema, Pinnularia, Melosira, Frustulia, Surirella (Bacillariophyceae); Ceratium (Dinophyceae); Euglena, Epistylis (Protozoa); Keratella, Brachionus (Rotifera); Daphnia (Cladocera) and Diaptomus, Cyclops (Copepoda). The results of diversity indices were calculated and values of Margalef species richness index (5.565-surface and 5.215subsurface) and Shannon-Wiener index (1.534-surface and 1.512-subsurface) were more in treatment four at both surface and subsurface levels of the pond ecosystems. The value of Pielou's evenness index was more in treatment three for surface waters $(0.8783)$ where as in subsurface waters $(0.9651)$, it was more in treatment 4 (Table 2).
In the surface level, Bacillariophyceae was the dominant group with percentage composition of $56.7 \pm 4.0,59.1 \pm 5.2$, $45.9 \pm 4.8$ and $60.6 \pm 5.0$ in treatments $1,2,3$ and 4 , respectively. The mean representations of Chlorophyceae in the total plankton were $27.5 \pm 2.9,26.8 \pm 4.2,36.4 \pm 5.2$ and $23 \pm 5.6$ for treatment $1,2,3$ and 4, respectively. Percentage composition of Myxophyceaean group were 4.6 $\pm 1.4,3.5 \pm 1.1,5.0 \pm 1.3$ and $2.0 \pm 0.5$ and those of Chrysophyceae and Dinophyceae were $1.9 \pm 0.7,3.0 \pm 1.0,2.1 \pm 0.7,2.3 \pm 0.7$ and $2.1 \pm 0.7,2.2 \pm 0.60$, $1.1 \pm 0.30,1.0 \pm 0.30$ in the four treatments, respectively. Copepods were the dominant group in the animal assemblages at the surface level with means of $3.0 \pm 1.20,2.3 \pm 0.80$, $4.0 \pm 1.90$ and $5.0 \pm 2.30$ for treatment $1,2,3$ and 4 , respectively. Availability of Protozoans and Rotifers were 1.5 \pm 0.70 , $0.6 \pm 0.20,3.1 \pm 1.10,3.3 \pm 1.30$ and $1.6 \pm 0.90,1.9 \pm 0.60$, $1.1 \pm 0.50,1.1 \pm 0.40$. The mean percentage compositions of 


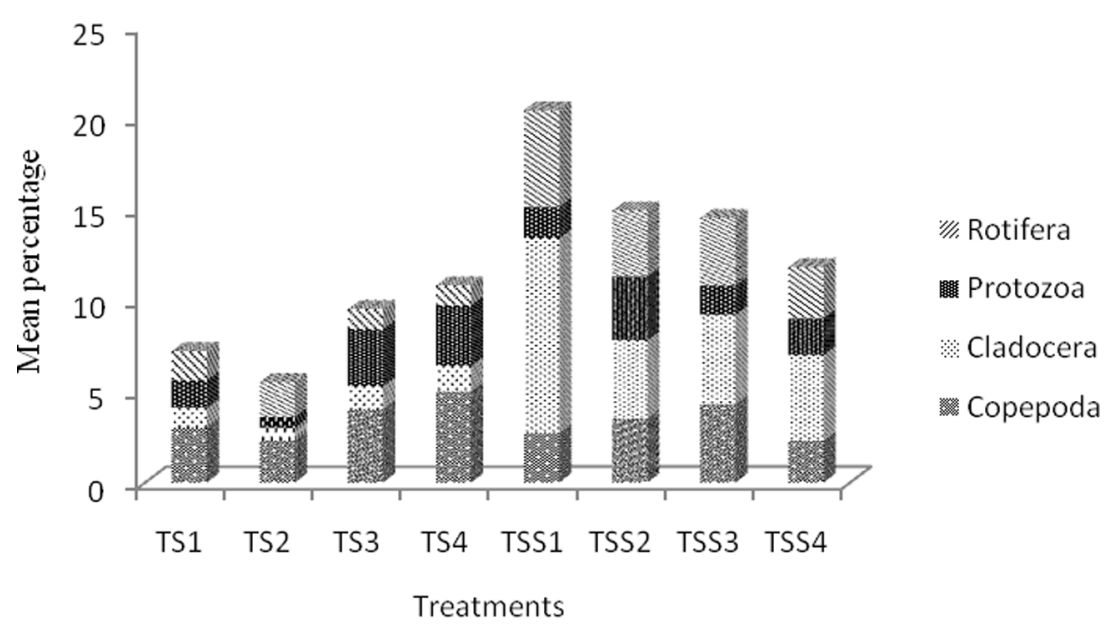

Fig. 4. Percentage compositions of animal assemblages at surface (TS1-TS4) and subsurface (TSS1-TSS4) levels of waters of ponds under four different treatments during the study period.

Table 2. Diversity indices of periphyton in surface waters and subsurface waters of pond ecosystems.

\begin{tabular}{|c|c|c|c|c|}
\hline Treatments & Number of species $(S)$ & Margalef species richness $(d)$ & Pielou's evenness index $\left(J^{\prime}\right)$ & Shannon-Wiener index $H^{\prime}(\log 10)$ \\
\hline \multicolumn{5}{|c|}{ Surface waters } \\
\hline TS1 & 42 & 4.884 & 0.8312 & 1.349 \\
\hline TS3 & 43 & 4.862 & 0.8783 & 1.435 \\
\hline TS4 & 48 & 5.565 & 0.8493 & 1.534 \\
\hline TSS1 & 37 & 4.736 & 0.9231 & 1.498 \\
\hline TSS2 & 36 & 4.591 & 0.9331 & 1.452 \\
\hline TSS3 & 40 & 4.973 & 0.9479 & 1.499 \\
\hline TSS4 & 46 & 5.215 & 0.9651 & 1.512 \\
\hline
\end{tabular}

Cladocerans were higher in treatments 1,3 and 4 than 2 with abundance of $1.1 \pm 0.70,1.3 \pm 0.50,1.4 \pm 0.60$ and $0.7 \pm 0.3$ in treatment 2 .

At the subsurface level, the counts of Bacillariophyceae were lower than the surface level with percentage composition of $38.2 \pm 2.16,36.2 \pm 4.98,42.6 \pm 4.67$ and $50.8 \pm 3.70$ Chlorophyceae comprised $35.4 \pm 2.96,36.4 \pm 5.27,36.4 \pm 5.59$ and $28.2 \pm 3.97$. The Myxophycean composition was highest in treatment $2(6.3 \pm 1.06)$ followed by treatments $3(2.6 \pm 0.51)$, $4(3.9 \pm 1.19)$ and $1(4.9 \pm 1.34)$. Chrysophyceae and Dinophyceae intensities were $0.3 \pm 0.13,3.4 \pm 1.28,2.4 \pm 0.85$, $3.5 \pm 0.96$ and $0.7 \pm 0.19,2.9 \pm 0.98,1.4 \pm 0.43,1.8 \pm 0.62$, respectively.

The abundance of Cladocerans at the subsurface level were higher than those at the surface level with abundance of $10.7 \pm 2.51 \%, 4.3 \pm 1.09 \%, 4.9 \pm 1.04 \%$ and $4.7 \pm 1.71 \%$. The copepods intensity were $2.7 \pm 0.77,3.5 \pm 1.14,4.3 \pm 0.96$, and $2.3 \pm 0.56$. The Protozoa's and Rotifers intensities were $1.7 \pm 0.50,3.5 \pm 0.96,1.6 \pm 0.34,2.00 \pm 0.82$ and $5.3 \pm 0.94$, $3.6 \pm 0.83,3.7 \pm 0.58,2.82 \pm 0.86$. In all the four treatments, the mean percentages of rotifers at the subsurface levels were higher than those at the surface levels.

\subsection{Water quality}

Temperature and depth of water were in the ranges of 20.8 $30.2^{\circ} \mathrm{C}$ and $0.8-1.8 \mathrm{~m}$. Water quality parameters in treatment $1,2,3$ and 4 were in the ranges of $\mathrm{pH} 7.4-8.5,8.0-8.4,7.4-8.4$, 7.4-8.4, dissolved oxygen 3.6-5.3, 3.6-5.0, 4.0-5.4, 3.5$6.1 \mathrm{mg} / \mathrm{l}$, ammonium-nitrogen 4.15-11.74, 2.68-14.38, 5.10 $19.88, \quad 6.08-22.66 \mu \mathrm{g}$-at N/l, nitrite-nitrogen 4.87-25.58, 4.63-24.32, 5.60-26.33, 7.94-28.95 $\mu \mathrm{g}$-at N/1, nitrate-nitrogen $10.18-40.11,10.12-33.86,10.04-41.09,10.06-48.98 \mu \mathrm{g}-$ at N/1, phosphate-phosphorus $0.12-0.5,0.08-0.48,0.03-0.4$, $0.04-0.54 \mathrm{mg} / 1$ and dissolved organic matter $2.2-5.65,2.10$ $6.5,4.2-8.60,5.2-9.50 \mathrm{mg} / 1$.

\section{Discussion}

The periphytic forms are considered as both a trophic resource and indicator of the environmental conditions (Azim et al., 2005; Rai et al., 2008). The ponds were stocked with carp fingerlings with a stocking density at 5000/ha with daily 
manuring. The water quality parameters were in the normal range since the ponds were applied with split doses of manure and fertilizer, no algal bloom formation was encountered. As the ponds were stocked with carp fingerlings at a density of $5000 /$ ha in proportions of catla $15 \%$, rohu $25 \%$, mrigal $25 \%$, silver carp $30 \%$ and grass carp $5 \%$ as a normal extensive fish culture practice which also supported non algal blooming in the ponds. Albay and Akçaalan (2008) and Cantonati and Spitale (2009) further analyzed the interactions between periphyton, water quality and other biotic communities. In the present study cow manure which is raw organic manure usually used in carp production showed lower periphytic counts and species diversity. One of the major goals in the present experiment was also to standardize the dose of biogas slurry applications in carp culture through ecological investigations, the periphytic counts and diversity in treatment 4 was higher than treatments 2 and 3 . The total nitrogen and phosphorus inputs in treatment $4\left(11.9 \mathrm{mg} \mathrm{N} / \mathrm{m}^{2} /\right.$ day, $19.2 \mathrm{mg} \mathrm{P} /$ $\mathrm{m}^{2} /$ day) was lower than treatment 1 ( $37.3 \mathrm{mg} \mathrm{N} / \mathrm{m}^{2} /$ day, $5.4 \mathrm{mg} \mathrm{P} / \mathrm{m}^{2} /$ day) and to bring out the advantages of applications of biogas slurry. Nitrogen and phosphorus inputs in treatment 2 $\left(\mathrm{mg} \mathrm{N} / \mathrm{m}^{2} /\right.$ day, $\mathrm{mg} \mathrm{P} / \mathrm{m}^{2} /$ day) and treatment $3\left(\mathrm{mg} \mathrm{N} / \mathrm{m}^{2} /\right.$ day, $\mathrm{mg} \mathrm{P} / \mathrm{m}^{2} /$ day) showed a medium range of periphyton counts and diversity. In treatment 2 the dose of manure application at $15 \mathrm{t} / \mathrm{ha} /$ yr along with inorganic fertilizer at the recommended dose proved that it was not the optimum manure application level. Similarly in treatment 3 only biogas slurry application at $30 \mathrm{t} / \mathrm{ha} /$ yr resulted in lesser periphyton counts and diversity than treatment 4 . With the provision of $1 \%$ feed of the total fish biomass applied in split doses supplied on a daily basis and biogas slurry at $30 \mathrm{t} / \mathrm{ha} / \mathrm{yr}$ in treatment 4 showed higher counts of periphyton, which could be due to the higher nutrient availability from the mineralization of the easily decomposable substrate and the differences with regard to manurial applications were demonstrable in the present investigation. In all the treatments total numbers of species were fewer in subsurface (36-46 nos.) and higher at surface levels (42-48 nos.). It was conspicuous that the Chlorophycean fraction was higher in periphyton of all the slurry-applied ponds. While the occurrence of higher periphytic counts along with dominance of algal fraction in the surface waters as in the present study has been observed by several workers in ponds, lakes and rivers (Sladeckova and Sladecek, 1990; Verdegem, 2002; Rimet and Bouchez, 2012) and the component of algal assemblages in the subsurface periphyton was comparatively low.

Diatoms were the most dominant algal forms in both surface and subsurface levels of the periphyton, as also observed by Wahab et al. (1999), Caputi et al. (2005) and Pandit et al. (2014). The forms encountered in the periphytic assemblages could be categorized into the following in terms of their habitat viz., filamentous green algae (e.g., Oedogonium) and diatoms (e.g., Melosira); prostrate or heterotrichous green algae (e.g., Bulbocheate); unicellular stalked algae (e.g., Gomphonema); unicellular forms mostly diatoms (e.g., Amphora); unicellular forms, mostly planktonic but loosely attached with or without mucilage (e.g., Navicula) and small colonial algae loosely or firmly attached by mucilage (e.g., Scenedesmus) (Philipose, 1967). This indicated greater availability of decomposed organic matter for their colonization in slurry-applied ponds. There was marginal increased colonization of periphytic substrates in the subsurface waters by protozoans and rotifers, the protozoans showed higher percentage representations in the surface waters in slurryapplied ponds as compared to other treatments. In the present study diversity indices were used to characterize species abundance and their relationship in the pond ecosystems. The highest periphyton diversity was recorded in treatment 4 for both surface and subsurface waters of the pond ecosystems. Results of this investigation provide information on variations in species and community structure of different inputs of raw and processed manures to pond ecosystems and it can be regarded as ecological and environmental manipulations and impact on the communities.

With no significant seasonal variations, the fluctuations in compositions of periphyton among the treatments and the depths specify the effects of the nature of the inputs. The extent of differences between the periphyton counts in the surface and bottom waters in the four treatments were $44.8 \%, 28.5 \%$, $16.9 \%$ and $14.9 \%$. Reduced penetration of sunlight due to turbidity caused by the traditional manurial practice of cow manure application could be causing the reduction in treatment 1, as also recorded by Philipose et al. (1976), uniform nutrient availability in the water column in ponds under slurry applications is also contributing to the observed pattern of periphyton settlement (Asaduzzaman et al., 2010; Radhakrishnan and Sugumaran, 2010; Ahsan et al., 2014). The present low-cost substrate based study showed higher populations of periphyton in slurry-applied ponds on a mean basis.

\section{Conclusion}

With no information available on periphytic community diversity in both cow manure and biogas slurry treated carp culture ponds the present research was conducted to demonstrate the advantages of biogas slurry applications over raw cow manure applications which is an age old and traditionally used manure in Indian carp culture. Manuring with biogas slurry was done at three levels to standardize the dose of applications of biogas slurry manure not commonly used. In freshwater pond culture, application of organic manure or inorganic fertilizers is applied under iso nitrogenous basis to supplement $100 \mathrm{~kg} \mathrm{~N}$ and $50 \mathrm{~kg} \mathrm{P} / \mathrm{ha} / \mathrm{yr}$ as also experienced in agricultural systems. Adding up of both fertilizer and manure leads to increased colonization and abundance of the attached algal communities for achieving better production levels. The mean periphyton counts in the surface and subsurface waters of the fish ponds with applications of cow manure at $10 \mathrm{t} / \mathrm{ha} / \mathrm{yr}$, urea at $100 \mathrm{~kg} \mathrm{~N} /$ $\mathrm{ha} / \mathrm{yr}$ and single super phosphate at $50 \mathrm{~kg} \mathrm{P} / \mathrm{ha} / \mathrm{yr}$ in the first treatment; biogas slurry at $15 \mathrm{t} / \mathrm{ha} / \mathrm{yr}$ and inorganic fertilizers as in the previous treatment in the second treatment; biogas slurry at $30 \mathrm{t} / \mathrm{ha} / \mathrm{yr}$ in the third and biogas slurry at $30 \mathrm{t} / \mathrm{ha} / \mathrm{yr}$ with supplementary feed were $333,365,407,433 / \mathrm{cm}^{2} /$ day and $230,284,348,377 / \mathrm{cm}^{2} /$ day, respectively. Higher counts were observed in treatment 4 , followed by treatments 3,2 and 1 showing significant differences. The total numbers of species at the surface level were higher in all the treatments were in the ranges of 42-48 numbers and lower in subsurface level in the ranges of 36-46 numbers. The periphyton counts and species diversity in the surface waters were considerably higher compared to subsurface levels in all the treatment. In order to 
increase carp production utilizing organic manures, environmental manipulations were made under conditions where the periphytic substrates were not provided. Information on variations in species and community structure of periphyton inputs of raw and processed manure biogas slurry where there was a preponderance of epilithic algal forms that could be harvested for secondary productivity to enhance carp production through provision of suitable substrates.

Acknowledgement. The present study was financed by Department of Non Conventional Energy Sources (DNES), New Delhi, India.

\section{References}

Ahsan ME, Sharker MR, Alam MA, Siddik MAB, Nahar A. 2014. Effects of addition of tilapia and periphyton substrates on water quality and abundance of plankton in freshwater prawn culture ponds. Int J Scient Technol Res 3(2): 272-278.

Albay M, Akçaalan R. 2008. Effects of water quality and hydrologic drivers on periphyton colonization on Sparganium erectum in two Turkish lakes with different mixing regimes. Environ Monit Assess 146: 171-181.

APHA, American Water Works Association, Water Pollution Control Federation. 2012. Standard methods for the examination of water and wastewater, 22nd ed. Washington, DC: American Public Health Association, 1360 pp.

Asaduzzaman M, Wahab MA, Verdegem MCJ, Azim ME, Haque S, Salam MA. 2008. C/N ratio control and substrate addition for periphyton development jointly enhance freshwater prawn Macrobrachium rosenbergii production in ponds. Aquaculture 280(1-4): 117-123.

Asaduzzaman M, Wahab MA, Verdegem MCJ, et al. 2010. Effects of carbohydrate source for maintaining a high $\mathrm{C}: \mathrm{N}$ ratio and fish driven re-suspension on pond ecology and production in periphyton based freshwater prawn farming systems. Aquaculture 301: $37-46$.

Ayyappan S. 1987. Investigations on the limonology and microbial ecology of a lentic habitat. Ph.D. Thesis, Bangalore University, Bangalore, $326 \mathrm{pp}$.

Azim ME, Wahab MA, van Dam AA, Beveridge MCM, Verdigem MCJ. 2001. The potential of periphyton-based culture of two Indian major carps, rohu Labeo rohita (Hamilton) and gonia Labeo gonius (Linnaeus). Aquac Res 32: 209-216.

Azim ME, Wahab MA, van Dam AA, Beveridge MCM, Verdigem MCJ. 2005. Periphyton and aquatic production: an introduction. In: Azim ME, Vedegem MCJ, van Dam AA, Beveridge MCM, eds. Periphyton - ecology, exploitation and management. Cambridge: CABI Publishing, pp. 1-14.

Barbiero RP. 2000. A multi-lake comparison of epilithic diatom communities on natural and artificial substrates. Hydrobiologia 438: $157-170$.

Cantonati M, Spitale D. 2009. The role of environmental variables in structuring epiphytic and epilithic diatom assemblages in springs and streams of the Dolomiti Bellunesi National Park (southeastern Alps). Fundam Appl Limnol: Arch Hydrobiol 174: 117-133.

Caputi K, Buric Z, Olujic G. 2005. Vertical distribution of periphytic diatoms in the karstic Zrmanja River (Croatia). Acta Bot Croat 64 (2): 227-236.

Clarke KL, Gorley RN. 2006. Primer v6.1.10: user manual/tutorial PRIMER-E. Plymouth: Plymouth Routines in Multivariate Ecological Research.
Debenest T, Pinelli E, Coste M, et al. 2009. Sensitivity of freshwater periphytic diatoms to agricultural herbicides. Aquat Toxicol 93(1): $11-17$.

Dempster PW, Beveridge MCM, Baird DJ. 1993. Herbivory in the tilapia Oreochromis niloticus: a comparison of feeding rates on phytoplankton and periphyton. J Fish Biol 43: 385-392.

Dharmaraj M, Manissery JK, Keshavanath P. 2002. Effects of a biodegradable substrate, sugarcane bagasse and supplemental feed on growth and production of fringe-lipped peninsula carp, Labeo fimbriatus (Bloch). Acta Ichthyol Piscat 32(2): 137-144.

Edmondson WT, ed. 1959. Fresh-water biology, 2nd ed. New York and London: John Wiley \& Sons, Inc., 1148 pp.

El-Sabaawi R, Harrison PJ. 2006. Interactive effects of irradiance and temperature on the photosynthetic physiology of the pennate diatom Pseudo-nitzschia granii (Bacillariophyceae) from the northeast subarctic Pacific. J Phycol 42: 778-785.

Huchette SMH, Beveridge MCM. 2008. Technical and economical evaluation of periphyton-based cage culture of tilapia (Oreochromis niloticus) in tropical freshwater cages. Aquaculture 218(1-4): 219-234.

Jobgen AM, Palm A, Melkonian M. 2004. Phosphorus removal from eutrophic lakes using periphyton on submerged artificial substrata. Hydrobiologia 528: 123-142.

Kaggwa RC, Kasule D, van Dam AA, Kansiime F. 2006. An initial assessment of the use of wetland plants as substrates for periphyton production in seasonal wetland, fish ponds in Uganda. Int J Ecol Environ Sci 32(1): 63-74.

Keshavanath P, Gangadhar B, Ramesh TJ, et al. 2001. Use of artificial substrates to enhance production of freshwater herbivorous fish in pond culture. Aquac Res 32: 189-197.

Keshavanath P, Gangadhar B, Ramesh TJ, van Dam AA, Beveridge MCM, Verdegem MCJ. 2002. The effect of periphyton and supplemental feeding on the production of the indigenous carps Tor Khudree and Labeo fimbriatus. Aquaculture 213: 207-218.

Maiti SK, Saha S, Adhikary S, Mukhopadhyay A, Saha T. 2014. Seasonal variation of phytoplankton diversity in relation to eutrophication of Mathura Beel, a floodplain lake in West Bengal, India. Asian J Water Environ Pollut 11(2): 37-44.

Milstein A, Peretz Y, Harpaz S. 2009. Culture of organic tilapia to market size in periphyton-based ponds with reduced feed inputs. Aquac Res 40(1): 55-59.

Nasser KMM, Sureshkumar S. 2014. Habitat wise variation in periphytic microalgal assemblages in the Vazhachal forest division of Chalakkudy River basin. Int J Curr Microbiol Appl Sci 3(6): 649-658.

Pandit AK, Farooq S, Shah JA. 2014. Periphytic algal community of Dal Lake in Kashmir Valley, India. Res J Environ Sci 8(7): 391-398.

Pfeiffer TŽ, Mihaljević M, Špoljarić D, Stević F, Plenković-Moraj A. 2015. The disturbance-driven changes of periphytic algal communities in a Danubian floodplain lake. Knowl Manag Aquat Ecosyst 416: 02.

Philipose MT. 1967. Chlorococcales. New Delhi: Indian Council of Agricultural Research, 365 pp.

Philipose MT, Nandy AC, Chakraborty DP, Ramakrishna KV. 1976. Studies on the distribution in time and space of the periphyton pond at Cuttack., India, No. 21. Barrackpore, India: Central Inland Fish. Res. Inst., 43 pp.

Radhakrishnan MV, Sugumaran E. 2010. Fluctuations in zooplankton density on sugarcane bagasse substrate used for fish culture. American-Eurasian J Sci Res 5(2): 153-155.

Rai S, Yi Y, Wahab MdA, Bart AN, Diana JS. 2008. Comparison of rice straw and bamboo stick substrates in periphyton-based carp polyculture systems. Aquac Res 39(5): 464-473. 
Rimet F, Bouchez A. 2012. Life-forms, cell-sizes and ecological guilds of diatoms in European rivers. Knowl Manag Aquat Ecosyst 406: 01.

Rusanov AG, Khromov VM. 2016. Longitudinal distribution of periphyton algae in the Moskva river under eutrophication. Water Resour 43(3): 513-521.

Saha S, Saha T, Basu P. 2016. Seasonal changes in zooplankton and macro-fauna populations of the east Calcutta wetland fish ponds. Proceedings of the Zoological Society, pp. 1-9.

Shankar KM, Mohan CV, Nandeesha MC. 1998. Promotion of substrate based microbial biofilm in ponds - a low cost technology to boost fish production. NAGA ICLARM Q 21(OctoberDecember): 18-22.

Sladecek V, Sladeckova A. 1964. Determination of the periphyton production by means of the glass slide method. Hydrobiologia 23 (1-2): $125-158$.
Sladeckova A, Sladecek V. 1990. Periphyton in a stabilization system. Acta Hydrochim Hydrobiol 18(5): 557-562.

van Dam AA, Beveridge MCM, Azim ME, Verdigem MCJ. 2002. The potential of fish production based on periphyton. Rev Fish Biol Fish 12: 1-31.

Verdegem MCJ. 2002. The potential of fish production based on periphyton. Rev Fish Biol Fish 12: 1-31.

Wahab MA, Azim ME, Ali MH, Beveridge MCM, Khan S. 1999. The potential of periphyton-based culture of the native major carp Culibaush, Labeo calbasu (Ham.). Aquac Res 30: 1-11.

Wang J, Jin P, Bishop P, Li F. 2011. Upgrade of three municipal wastewater treatments lagoons using a high surface area media. Front Environ Sci Eng China 6: 288-293.

Wetzel RG. 2001. Limnology, IIIrd ed. New York: Academic Press, p. 1006, ISBN-13: 9780127447605.

Cite this article as: Das M, Behera PR, Dash B. 2017. Periphyton communities in carp culture ponds treated with cow manure and biogas slurry. Aquat. Living Resour. 30: 25 